\title{
Abundance and community composition of methanotrophs in a Chinese paddy soil under long-term fertilization practices
}

\author{
Yong Zheng • Li-Mei Zhang • Yuan-Ming Zheng • \\ Hongjie Di • Ji-Zheng He
}

Received: 23 July 2008 / Accepted: 8 October 2008 / Published online: 29 October 2008

(C) Springer-Verlag 2008

\begin{abstract}
Background, aim, and scope As the second most important greenhouse gas, methane $\left(\mathrm{CH}_{4}\right)$ is produced from many sources such as paddy fields. Methane-oxidizing bacteria (methanotrophs) consume $\mathrm{CH}_{4}$ in paddy soil and, therefore, reduce $\mathrm{CH}_{4}$ emission to the atmosphere. In order to estimate the contribution of paddy fields as a source of $\mathrm{CH}_{4}$, it is important to monitor the effects of fertilizer applications on the shifts of soil methanotrophs, which are targets in strategies to combat global climate change. In this study, real-time polymerase chain reaction (PCR) and denaturing gradient gel electrophoresis (DGGE) based on $16 \mathrm{~S}$ rRNA and pmoA genes, respectively, were used to analyze the soil methanotrophic abundance and community diversity under four fertilization treatments: urea $(\mathrm{N})$, urea and potassium chloride (NK), urea, superphosphate, and potassium chloride (NPK), and urea, superphosphate, potassium chloride, and crop residues $(\mathrm{NPK}+\mathrm{C})$, compared to an untreated control (CON). The objective of this study was to examine whether soil methanotrophs responded to the long-term, different fertilizer regimes by using a
\end{abstract}

Responsible editor: Chengrong Chen

Y. Zheng · L.-M. Zhang · Y.-M Zheng · H.J. Di · J.-Z. He $(\bowtie)$

State Key Laboratory of Urban and Regional Ecology,

Research Center for Eco-Environmental Sciences,

Chinese Academy of Sciences,

Beijing 100085, China

e-mail: jzhe@rcees.ac.cn

\section{Y. Zheng}

Graduate University, Chinese Academy of Sciences, Beijing 100049, China

H.J. Di

Agriculture and Life Sciences Division, Lincoln University, P.O. Box 84, Canterbury, New Zealand combination of quantitative and qualitative molecular approaches.

Materials and methods Soil samples were collected from the Taoyuan Experimental Station of Agro-ecosystem Observation at Changde $\left(28^{\circ} 55^{\prime} \mathrm{N}, 111^{\circ} 26^{\prime} \mathrm{E}\right)$, central Hunan Province of China, in July 2006. Soil DNAs were extracted from the samples, then the 16S rRNA genes were quantified by real-time PCR and the $p m o A$ genes were amplified via general PCR followed by DGGE, cloning, sequencing, and phylogenetic analysis. The community diversity indices were assessed through the DGGE profile.

Results Except for NPK, other treatments of N, NK, and $\mathrm{NPK}+\mathrm{C}$ showed significantly higher copy numbers of type I methanotrophs $\left(7.0-9.6 \times 10^{7}\right)$ than $\mathrm{CON}\left(5.1 \times 10^{7}\right)$. The copy numbers of type II methanotrophs were significantly higher in NPK $+\mathrm{C}\left(2.8 \times 10^{8}\right)$ and NK $\left(2.5 \times 10^{8}\right)$ treatments than in $\mathrm{CON}\left(1.4 \times 10^{8}\right)$. Moreover, the ratio of type II to type I methanotrophic copy numbers ranged from 1.88 to 3.32 , indicating that the type II methanotrophs dominated in all treatments. Cluster analyses based on the DGGE profile showed that the methanotrophic community in $\mathrm{NPK}+\mathrm{C}$ might respond more sensitively to the environmental variation. Phylogenetic analysis showed that $81 \%$ of the obtained pmoA sequences were classified as type I methanotrophs. Furthermore, the type I-affiliated sequences were related to Methylobacter, Methylomicrobium, Methylomonas, and some uncultured methanotrophic clones, and those type IIlike sequences were affiliated with Methylocystis and Methylosinus genera.

Discussion There was an inhibitory effect on the methanotrophic abundance in the $\mathrm{N}$ and a stimulating effect in the $\mathrm{NK}$ and $\mathrm{NPK}+\mathrm{C}$ treatments, respectively. During the ricegrowing season, the type II methanotrophs might be more profited from such a coexistence of low $\mathrm{O}_{2}$ and high $\mathrm{CH}_{4}$ concentration environment than the type I methanotrophs. 
However, type I methanotrophs seemed to be more frequently detected. The relatively complex diversity pattern in the $\mathrm{NPK}+\mathrm{C}$ treatment might result from the strong $\mathrm{CH}_{4}$ production.

Conclusions Long-term fertilization regimes can both affect the abundance and the composition of the type I and type II methanotrophs. The inhibited effects on methanotrophic abundance were found in the $\mathrm{N}$ treatment, compared to the stimulated effects from the NK and $\mathrm{NPK}+\mathrm{C}$ treatments. The fertilizers of nitrogen, potassium, and the crop residues could be important factors controlling the abundance and community composition of the methanotrophs in the paddy soil.

Recommendations and perspectives Methanotrophs are a fascinating group of microorganisms playing an important role in the biogeochemical carbon cycle and in the control of global climate change. However, it is still a challenge for the cultivation of the methanotrophs, although three isolates were obtained in the extreme environments very recently. Therefore, future studies will be undoubtedly conducted via molecular techniques just like the applications in this study.

Keywords 16S rRNA gene - DGGE .

Long-term fertilization · Methanotrophs · Paddy soil ·

pmoA gene $\cdot$ Real-time polymerase chain reaction (PCR)

\section{Background, aim, and scope}

Methane $\left(\mathrm{CH}_{4}\right)$ is the second most abundant carboncontaining gas in the atmosphere and contributes approximately $18 \%$ to the global warming (IPCC 2007). The atmospheric methane concentration is determined by the balance of methane production and methane oxidation. Rice cultivation is one of the major sources of methane, which annually emits $60 \mathrm{Tg} \mathrm{CH} \mathrm{CH}_{4}$ into the atmosphere (Lowe 2006). Rice is one of the most important food crops to feed the growing population, especially in Asia (Krüger and Frenzel 2003; Conrad et al. 2006). In order to maximize rice grain yields, rice cultivation needs to be intensified by strengthening and improving the agronomic practices, such as fertilizer applications.

Before releasing into the atmosphere, the produced $\mathrm{CH}_{4}$ is subject to oxidation by methane-oxidizing bacteria (methanotrophs) in the surface soil layer and the rhizosphere. Methanotrophs, gram-negative bacteria that utilize methane as their sole source of carbon and energy, play an important role in regulating $\mathrm{CH}_{4}$ emission from the paddy field. Methanotrophs are obligate aerobes and classified into two main groups (type I and type II) differing in phylogeny, physiology, morphology, and biochemistry (Hanson and Hanson 1996). Type I methanotrophs belong to the gamma proteobacteria and assimilate the intermediate formaldehyde via the ribulose monophosphate pathway.
Type II methanotrophs, however, belong to the alpha proteobacteria and utilize the serine pathway for assimilating formaldehyde.

Many methanotrophs are difficult to cultivate. Cultureindependent molecular approaches have been widely used to assess the diversity and activity of methanotrophs present in the natural environment. These approaches use phylogenetic and functional gene probes to detect and analyze methanotrophs directly from environmental samples without cultivation (Murrell et al. 1998). For discriminating the type I and type II methanotrophs, different polymerase chain reaction (PCR) primers were designed to amplify $16 \mathrm{~S}$ rRNA gene fragments of these two distinct groups in earlier studies (Henckel et al. 1999; Wise et al. 1999). Since then, the molecular analysis on the basis of specific 16S rRNA gene probes that target either type I or type II methanotrophs were successfully applied in detecting these two methane oxidizers. For example, type I methanotrophs were found more sensitive to the presence of the rice plants than type II methanotrophs (Bodelier et al. 2000). Soil methanotrophic community structure could be altered after a long-term herbicide application (Seghers et al. 2003).

In addition to the $16 \mathrm{~S}$ rRNA gene, functional genes of methanotrophs were also used to detect the presence and abundance of the methane oxidizers (Fjellbirkeland et al. 2001; Horz et al. 2001). These functional genes include pmoA, mmoX, and mxaF, which encode subunits of particulate methane monooxygenase, soluble methane monooxygenase, and methanol dehydrogenase, respectively. Among these functional genes, $p m o A$ is present in all known methanotrophs with the only exception of Methylocella spp. Furthermore, sequence-based pmoA phylogeny is consistent with the 16S rRNA-based phylogeny. Thus, the pmoA gene is a favorable functional gene and widely used to detect methanotrophs in soils (Holmes et al. 1999; Mohanty et al. 2007).

Our previous investigations showed that long-term fertilization practices could result in significant shifts in the diversity of soil bacteria and fungi (Ge et al. 2008; He et al. 2008) and in the abundance and community composition of some soil functional microorganisms such as ammonia oxidizers (He et al. 2007; Shen et al. 2008). As an important player in carbon cycling in terrestrial ecosystems, soil methanotrophs should not be ignored. In this study, we proposed the following hypotheses to be tested: (1) long-term fertilizer applications result in changes in methanotrophic abundance and community composition in a paddy field and (2) type I and type II methanotrophs respond differently to the fertilization treatments. We thus collected paddy field soil samples from a long-term fertilization experimental site, and the abundance and community composition of the soil methanotrophs were investigated using real-time PCR and denaturing gradient 
gel electrophoresis (DGGE) based on both 16S rRNA and pmoA genes, respectively.

\section{Materials and methods}

\subsection{Site description and soil sampling}

Soil samples were collected from the Taoyuan Experimental Station of Agro-ecosystem Observation, the Chinese Academy of Sciences at Changde $\left(28^{\circ} 55^{\prime} \mathrm{N}, 111^{\circ} 26^{\prime} \mathrm{E}\right)$, central Hunan Province of China. This region has a centralnorth subtropical monsoon moist climate with a mean annual precipitation of $1,447.9 \mathrm{~mm}$ and a mean annual temperature of $16.5^{\circ} \mathrm{C}$. The paddy soil in this station was derived from quaternary red clay and classified as a waterloggogenic paddy soil. The land utilization was early rice plus late rice plus green manure annually since 1990 . Five treatments were selected in this study: (1) treatment 'CON', a control without fertilizers; (2) treatment ' $\mathrm{N}$ ' in which only nitrogen (N) fertilizer as urea was applied; (3) treatment ' $\mathrm{NK}$ ', which was treatment $\mathrm{N}$ plus $\mathrm{K}$ as potassium chloride; (4) treatment 'NPK', which was treatment NK plus $\mathrm{P}$ as superphosphate; and (5) treatment 'NPK $+\mathrm{C}$ ', which was treatment NPK plus recycled crop residues. Each treatment had three replicates which were arranged in fully randomized blocks. The annual amount of $\mathrm{N}, \mathrm{P}, \mathrm{K}$, and $\mathrm{C}$ were shown in Table 1 . The soil samples from three individual plots (each plot measured $4.1 \times$ $\left.8.1 \mathrm{~m}^{2}\right)$ per treatment were taken randomly from every replicate at horizon A (0-20 cm in depth) in July 2006. The samples were stored at $-20^{\circ} \mathrm{C}$ for DNA extraction and $4{ }^{\circ} \mathrm{C}$ for other analyses. Basic characteristics of the soil samples are listed in Table 2.

\subsection{Extraction of soil DNA}

Soil DNA was extracted from $0.5 \mathrm{~g}$ (fresh weight) soil samples using MoBio UltraClean ${ }^{\mathrm{TM}}$ soil DNA isolation kits (San Diego, CA, USA) according to the manufacturer's protocol with previously described modifications (He et al. 2007). For a more efficient elution of DNA from spin filter, a volume of $80 \mu \mathrm{L}$ of solution S5 was used.

2.3 Quantitative analysis of the methanotrophs by real-time PCR

Real-time PCR was performed on an iCycler iQ5 thermocycler (Bio-Rad). Amplification was performed in $25-\mu \mathrm{L}$ reaction mixtures by using SYBR ${ }^{\circledR}$ Premix Ex Taq $^{\mathrm{TM}}$ as described by the suppliers (Takara Bio, Otsu, Shiga, Japan). Two forward primers of MB10 $\gamma$ (5'-AAGCGGGGGAT CTTCGGACC-3') and MB9 $\alpha$ (5'-GTTCGGAATAACTC AGGG-3') and their common reverse primer 533r (5'TTACCGCGGCTGCTGGCAC-3') were used to determine the 16S rRNA gene copy numbers of the type I and type II methanotrophs, respectively (Henckel et al. 1999). The DNA extracts were tenfold diluted and used as template with a final content of 1-10 ng in each reaction mixture. Real-time PCR assay was carried out with the protocol for both target groups as follows: $95^{\circ} \mathrm{C}$ for 2 min followed by 36 cycles of $1 \mathrm{~min}$ at $94^{\circ} \mathrm{C}, 1 \mathrm{~min}$ at $60^{\circ} \mathrm{C}$, plate read at $83^{\circ} \mathrm{C}$. In each real-time PCR amplification, following the three temperature steps, a melting curve analysis was performed to confirm PCR product specificity by measuring fluorescence continuously as the temperature increased from $55^{\circ} \mathrm{C}$ to $95^{\circ} \mathrm{C}$. Data analysis was carried out with the iCycler software (version 1.0.1384.0 CR). The parameter $C_{\mathrm{t}}$ (threshold cycle) was determined as the cycle number at which a statistically significant increase in the reporter fluorescence was detected.

\subsection{Standard curve for real-time PCR}

The primer pairs $\mathrm{MB} 10 \gamma / 533 \mathrm{r}$ and $\mathrm{MB} 9 \alpha / 533 \mathrm{r}$ were applied to amplify type I and type II methanotroph-specific 16S rRNA gene fragments from the environmental DNA extract and Methylosinus sporium (NCIMB 11126), respectively. The PCR products were gel-purified with the Agarose Gel DNA Purification Kit (TaKaRa Biotechnology, Dalian, China) and ligated into the pGEM-T Easy Vector (Promega,

Table 1 The annual amount of the chemical and organic residue cycling fertilizers applied to the examined paddy field since 1990

\begin{tabular}{|c|c|c|c|c|c|c|}
\hline \multirow[t]{2}{*}{ Treatments } & \multicolumn{3}{|c|}{ Amount of fertilizer $\left(\mathrm{kg} \mathrm{ha}^{-1}\right)$} & \multicolumn{3}{|c|}{ Amount of organic residues $\left(\mathrm{kg} \mathrm{ha}^{-1}\right)^{\mathrm{a}}$} \\
\hline & $\mathrm{N}$ & $\mathrm{P}$ & $\mathrm{K}$ & $\mathrm{N}$ & $\mathrm{P}$ & $\mathrm{K}$ \\
\hline $\mathrm{CON}$ & 0 & 0 & 0 & 0 & 0 & 0 \\
\hline $\mathrm{N}$ & $262.5 / 182.3^{\mathrm{b}}$ & 0 & 0 & 0 & 0 & 0 \\
\hline NK & $262.5 / 182.3$ & 0 & 137.0/197.2 & 0 & 0 & 0 \\
\hline NPK & $262.5 / 182.3$ & 39.3 & $137.0 / 197.2$ & 0 & 0 & 0 \\
\hline $\mathrm{NPK}+\mathrm{C}$ & $262.5 / 182.3$ & 39.3 & 137.0/197.2 & 175.9 & 39.9 & 253.2 \\
\hline
\end{tabular}

${ }^{\text {a }}$ The amount of organic residue cycling is the average from 1990 to 2001

${ }^{\mathrm{b}}$ The former is the $\mathrm{N}$ and $\mathrm{K}$ fertilizer amount of 1990 to 1996 and the latter is the amount after 1996 
Table 2 The basic characteristics of the examined paddy soil under different fertilization treatments for 16 years

\begin{tabular}{lccccc}
\hline Treatments & $\mathrm{pH}\left(\mathrm{H}_{2} \mathrm{O}\right)$ & O.M. $\left(\mathrm{g} \mathrm{kg}^{-1}\right)$ & Total N $\left(\mathrm{g} \mathrm{kg}^{-1}\right)$ & Available P $\left(\mathrm{mg} \mathrm{kg}^{-1}\right)$ & Available K $\left(\mathrm{mg} \mathrm{kg}^{-1}\right)$ \\
\hline $\mathrm{CON}$ & $4.94 \pm 0.01 \mathrm{~b}$ & $29.2 \pm 1.1 \mathrm{~b}$ & $3.53 \pm 0.31 \mathrm{~b}$ & $19.1 \pm 3.06 \mathrm{c}$ & $47.1 \pm 6.02 \mathrm{~b}$ \\
$\mathrm{~N}$ & $4.99 \pm 0.03 \mathrm{~b}$ & $30.2 \pm 5.1 \mathrm{~b}$ & $3.73 \pm 0.47 \mathrm{~b}$ & $9.83 \pm 1.74 \mathrm{~d}$ & $41.2 \pm 7.50 \mathrm{~b}$ \\
$\mathrm{NK}$ & $5.15 \pm 0.07 \mathrm{a}$ & $30.5 \pm 5.0 \mathrm{~b}$ & $3.71 \pm 0.49 \mathrm{~b}$ & $20.9 \pm 4.69 \mathrm{c}$ & $148 \pm 29.3 \mathrm{a}$ \\
$\mathrm{NPK}$ & $4.80 \pm 0.09 \mathrm{c}$ & $33.1 \pm 7.5 \mathrm{~b}$ & $3.96 \pm 0.75 \mathrm{~b}$ & $89.2 \pm 2.86 \mathrm{~b}$ & $56.1 \pm 5.03 \mathrm{~b}$ \\
$\mathrm{NPK}+\mathrm{C}$ & $4.92 \pm 0.04 \mathrm{~b}$ & $47.7 \pm 2.0 \mathrm{a}$ & $5.39 \pm 0.14 \mathrm{a}$ & $155 \pm 6.13 \mathrm{a}$ & $152 \pm 20.9 \mathrm{a}$ \\
\hline
\end{tabular}

The letters (a-d) indicate significant differences between treatments at $P<0.05$

Madison, WI, USA), the ligation products were then used to transform Escherichia coli JM109 competent cells following the instructions of the manufacturer. After reamplification with the vector-specific primers T7/SP6 (an additional sequencing identification for type I methanotrophic clone was carried out), the positive clones were selected to extract plasmid DNA with a MiniBEST Plasmid Purification Kit (TaKaRa). The plasmid DNA concentrations were determined using a Nanodrop ${ }^{\circledR}$ ND-1000 UV-Vis Spectrophotometer (NanoDrop Technologies) and the copy numbers of 16S rRNA gene were calculated directly from the concentrations of the extracted plasmid DNA. Tenfold serial dilutions of a known copy number of the plasmid DNA were subjected to real-time PCR assay in triplicate to generate an external standard curve.

\subsection{PCR-DGGE analysis of the methanotrophic} community structure

In order to detect the methanotrophic diversity in the different fertilization treatments, a PCR-DGGE experiment was conducted to amplify methanotrophic pmoA gene fragment. The sequences of the forward and reverse primers were A189 (Holmes et al. 1999) and mb661 (Kolb et al. 2003). Notably, a GC clamp (CCC CCC CCC CCC CGC CCC CCG CCC CCC GCC CCC GCC GCC C) was attached to the $5^{\prime}$ end of A189. The PCR condition was described as follows. Briefly, 20 pmol of each primer, $10 \mathrm{nmol}$ of deoxyribonucleoside triphosphate, $75 \mathrm{nmol}$ of $\mathrm{MgCl}_{2}, 5 \mu \mathrm{L}$ of $10 \times$ PCR buffer, $2.5 \mathrm{U}$ of Taq DNA polymerase (TaKaRa), and approximately $10 \mathrm{ng}$ of template DNA were combined with superpurified $\mathrm{H}_{2} \mathrm{O}$ to a total volume of $50 \mu \mathrm{L}$ in a $0.5-\mathrm{mL}$ tube. A touchdown thermal cycle strategy involved an initial preheating step of $4 \mathrm{~min}$ at $94^{\circ} \mathrm{C}$ for melting double-stranded DNA. Then, a touchdown procedure (consisting of $1 \mathrm{~min}$ at $94^{\circ} \mathrm{C}$, annealing for $1 \mathrm{~min}$ at temperatures decreasing from $60^{\circ} \mathrm{C}$ to $52^{\circ} \mathrm{C}$ during the first 16 cycles, and ending with an extension step at $72^{\circ} \mathrm{C}$ for $1 \mathrm{~min}$ ) followed, additional 20 cycles (consisting of $1 \mathrm{~min}$ at $94^{\circ} \mathrm{C}, 1 \mathrm{~min}$ at $52^{\circ} \mathrm{C}$, and $1 \mathrm{~min}$ at $72^{\circ} \mathrm{C}$ ) and a final extension of $10 \mathrm{~min}$ at $72^{\circ} \mathrm{C}$ were performed.

The obtained PCR products were loaded on to $6 \%$ (vol/ vol) acrylamide/bisacrylamide (37.5:1) gel, which was made with a denaturing gradient ranging from $40 \%$ to $60 \%$. The electrophoresis was run in a DCode Universal Detection System Instrument (Bio-Rad Laboratories, Hercules, CA, USA) at a constant temperature of $60^{\circ} \mathrm{C}$ for $10 \mathrm{~min}$ at $150 \mathrm{~V}$ followed by $6 \mathrm{~h}$ at $120 \mathrm{~V}$. After running, the gel was stained with 1:10,000 SYBR Gold Nucleic Acid Gel Stain (Invitrogen Molecular Probes, Eugene, USA) for $30 \mathrm{~min}$ according to the manufacturer's instructions and then photographed with UV transillumination. Subsequently, a matrix of similarities between the densitometric curves of the band patterns was calculated based on the Dice coefficient with Quantity One 4.5.2 software (Bio-Rad). Finally, the DGGE patterns were clustered based on the unweighted pair-group arithmetic average (UPGAMA) clustering algorithm.

2.6 Cloning, sequencing, and phylogenetic tree construction

The DGGE gel strips of some distinguished bands among all treatments were excised and reamplified following previous PCR conditions. These PCR products were cloned by using the pGEM-T Easy Vector (Promega). Clones that contained correctly inserted fragments were selected and sequenced by using an ABI PRISM 3730 DNA analyzer (Sangon Biotechnology, Shanghai, China). The obtained sequences were manually proofread and corrected if necessary, edited and aligned using BioEdit version 4.8.5. These partial sequences of approximately $508 \mathrm{bp}$ were aligned to $p m o A$ gene sequences obtained from the National Center for Biotechnology Information (NCBI) database using the BLAST version 2.2.16 searching program. The most similar and representative GenBank sequences to the clones were extracted from the GenBank. Phylogenetic analyses were conducted using MEGA version 3.1 and the neighbor-joining trees were constructed using $p$-distance with 1,000 replicates to produce bootstrap values.

\subsection{Diversity indices}

The diversity indices, including richness index and Shannon index, were quantified and calculated based on DGGE data, respectively. Each detected band was defined as a specific phylotypes. The pixel intensity for each band was detected by Quantity One software and considered as the 
abundance of a specific phylotype for diversity estimations. Briefly, the Shannon index $(H)$ was calculated based on the following equations in which $H$ is the Shannon index, $N_{i}$ is the abundance of the $i$ th phylotype, $N$ is the total abundance of all phylotypes in the sample (lane of the DGGE gel), and $S$ is the number of phylotypes:

$H=-\sum_{i=1}^{S} p_{i} \ln p_{i}=-\sum_{i=1}^{S}\left(N_{i} / N\right) \ln \left(N_{i} / N\right)$

\subsection{Nucleotide sequence accession numbers}

The obtained sequences were submitted to the GenBank database under accession numbers EU193266-EU193301.

\section{Results}

\subsection{Methanotrophic abundance based on 16S rRNA gene}

The 16S rRNA gene copy numbers of type I and type II methanotrophs are shown in Fig. 1. For the type I methanotrophs, the fertilization treatments of $\mathrm{N}, \mathrm{NK}$, and $\mathrm{NPK}+\mathrm{C}$ showed significantly higher copy numbers $(7.0 \times$ $10^{7}, 9.6 \times 10^{7}$, and $8.3 \times 10^{7}$, respectively) than $\mathrm{CON}(5.1 \times$ $10^{7}$ ). There was no significant difference between the NPK and the CON. For the type II methanotrophs, the quantitative results showed that the copy numbers were signifi-

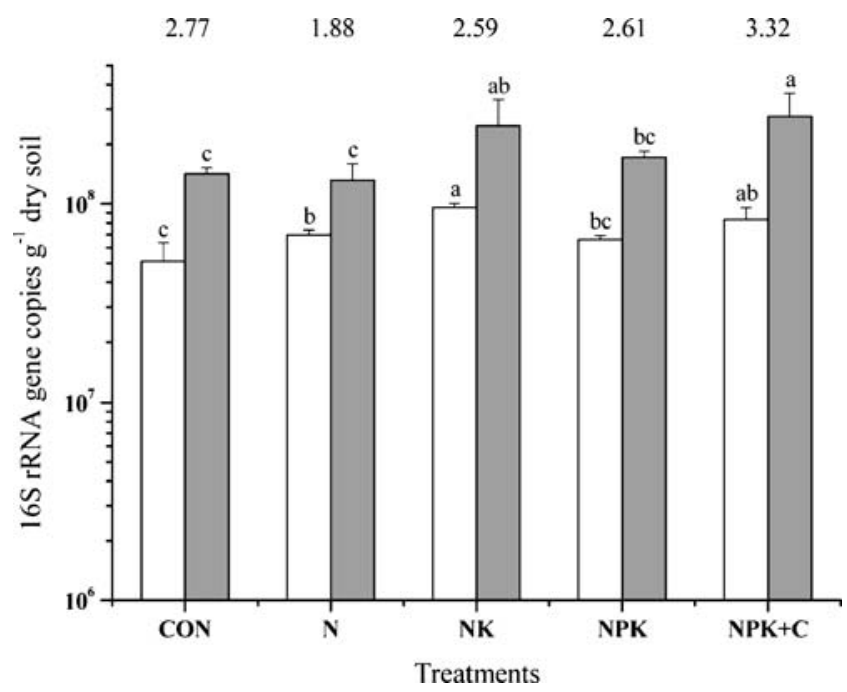

Fig. 1 Quantification of 16S rRNA gene copy numbers from type I (white bars) and type II methanotrophs (gray bars) in a Chinese paddy soil under different fertilization treatments. Ratios of type II to type I methanotrophic copy numbers are shown above the chart. The different letters above the bars indicate significant differences among treatments at $P<0.05$ cantly higher in the NPK $+\mathrm{C}\left(2.8 \times 10^{8}\right)$ and NK $\left(2.5 \times 10^{8}\right)$ treatments than in $\mathrm{CON}\left(1.4 \times 10^{8}\right)$. There was no significant difference among NPK $\left(1.7 \times 10^{8}\right), \mathrm{N}\left(1.3 \times 10^{8}\right)$, and CON. Interestingly, the ratio of type II to type I methanotrophic copy numbers ranged from 1.88 to 3.32 , indicating that the type II accounted for a significantly higher ratio than type I of the total methanotrophs in all the fertilization treatments.

\subsection{Methanotrophic community structure}

The DGGE profile of the methanotrophic community of the soil samples showed some variations among the treatments (Fig. 2a). It is clear that fewer bands and lower methanotrophic diversity were detected in the NK treatment (lanes 7-9) than the other two fertilization treatments of $\mathrm{N}$ and $\mathrm{NPK}+\mathrm{C}$ (Table 3). Cluster analyses (Fig. 2b) based on the DGGE profile showed that the $\mathrm{N}$ and CON treatments had a relatively similar banding pattern and clustered together initially, while the NK clustered together in another subcluster and clearly distinguished itself from the NPK $+\mathrm{C}$ treatment. This could also reflect that the soil methanotrophic community in the $\mathrm{NPK}+\mathrm{C}$ treatment might be responding more sensitively to the environmental variation here.

\subsection{Phylogenetic analysis of $p m o A$ gene clones} among the treatments

A total of 34 methanotrophic bands (numbering from 1 to 34 ) in the DGGE gel was excised for further cloning analysis (Fig. 2a). After the subsequent sequencing, we obtained 36 sequences, which were all identified as pmoA gene sequences. By aligning with the GenBank database, all retrieved sequences were classified into type I and type II methanotrophs (Fig. 3). Phylogenetic analysis of the methanotrophic pmoA gene sequences showed that 29 out of 36 sequences (up to $81 \%$ ) were classified as type I methanotrophs and the remaining seven sequences were related to type II methanotrophs. Especially in Fig. 3, band 3 and band 7 were both found to contain two sequences, which were further named as bands 3-1, 3-2, 7-1, and 7-2, respectively. However, bands 7-1 and 7-2 were not very closely related, although they were both classified into the Methylocystis genera. It was interesting to note that a significantly higher ratio $(80 \%)$ of sequences appeared in the upper part of the DGGE gel that were affiliated with Methylobacter, Methylomicrobium, Methylomonas, and some uncultured methanotrophic clones, and all these methanotrophic genera and clones were classified as type I methanotrophs (marked by shade in Fig. 3). Only $20 \%$ (three sequences including EU193271, EU193273, and EU193274) was classified into type II methanotrophs. Phylogenetic analysis of these type II-like sequences was affiliated with Methylocystis and Methylosinus genera. 
Fig. 2 a DGGE profile of methanotrophic pmoA gene fragments of soil samples under different fertilization treatments and $\mathbf{b}$ cluster analysis of left DGGE banding patterns. The small black triangles and numbers on each lane indicate the bands excised for further analysis

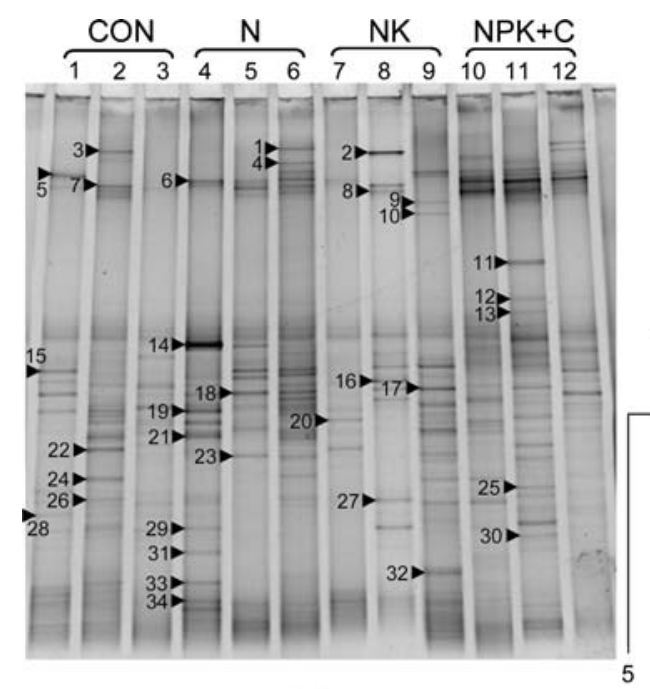

(a)

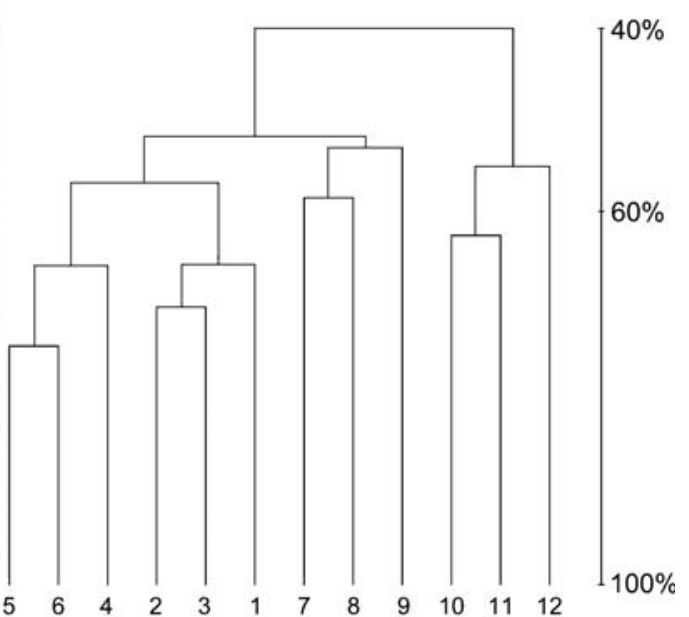

(b)

\section{Discussion}

4.1 Effects of fertilizer applications on soil methanotrophic abundance

Quantitative analysis on the basis of group-specific $16 \mathrm{~S}$ rRNA gene revealed that the size of total soil methanotrophs was subjected to the long-term fertilizer treatments. Compared with the fertilization treatments of $\mathrm{NK}$ and $\mathrm{NPK}+\mathrm{C}$, long-term $\mathrm{N}$ fertilization seemed to inhibit the soil methanotrophs, although higher type I methanotrophic $16 \mathrm{~S}$ rRNA gene copy numbers were found in the $\mathrm{N}$ than in the CON. As $\mathrm{N}$ fertilizer was applied in this study, urea is a $\mathrm{NH}_{4}{ }^{+}$-producing compound, and its inhibitory effect on methanotrophs was also demonstrated (Dubey and Singh 2000). In an earlier study, $\mathrm{He}$ et al. (2007) found that the lowest ammonia oxidizers population sizes were found in the N-treated upland red soil samples. The negative effects of $\mathrm{N}$ fertilizer on methane oxidizers and ammonia oxidizers were similarly found in paddy soil and upland soil samples, which were both collected from central Hunan Province of China. Additionally, Ge et al. (2008) previously found that $\mathrm{N}$ fertilizer was a key factor in controlling soil bacterial

Table 3 Diversity properties of paddy soil methanotrophs using DGGE bands pattern data associated with long-term different fertilization

\begin{tabular}{lcc}
\hline Treatments & Richness & Shannon $(H)$ \\
\hline CON & $19 \pm 2 \mathrm{~b}$ & $2.92 \pm 0.08 \mathrm{c}$ \\
$\mathrm{N}$ & $27 \pm 2 \mathrm{a}$ & $3.24 \pm 0.08 \mathrm{a}$ \\
$\mathrm{NK}$ & $19 \pm 2 \mathrm{~b}$ & $2.87 \pm 0.06 \mathrm{c}$ \\
$\mathrm{NPK}+\mathrm{C}$ & $23 \pm 2 \mathrm{a}$ & $3.08 \pm 0.02 \mathrm{~b}$ \\
\hline
\end{tabular}

The letters $(\mathrm{a}-\mathrm{c})$ indicate significant differences between treatments at $P<0.05$ community. In contrast to the $\mathrm{N}$ application, the application of NK fertilizers seemed to stimulate the growth of methanotrophs and led to an increase in the methanotrophic abundance. This result is in agreement with another field experiment where the amendment of potassium $(\mathrm{K})$ was suggested to be inhibiting methanogenic bacteria, but stimulating the methanotrophic bacterial population (Babu et al. 2006). Interestingly, in Table 2, a significantly higher content of available $\mathrm{K}$ was found in NK than in $\mathrm{CON}$ and $\mathrm{N}$, indicating that the $\mathrm{K}$ fertilizer may play an important role in upkeeping methanotrophic life processes. The NPK fertilizer had given relatively little effects on the soil methanotrophs. However, the treatment of $\mathrm{NPK}+\mathrm{C}$ fertilizers seemed to stimulate the soil methanotrophs, indicating that the application of recycled crop residues (rice straw) seemed to have a positive influence, both on the soil fertility (see Table 2) and on the soil methanotrophic population size. Dissimilarly, wheat straw was found to have no effect on methanotrophy (Hütsch 1998). We interpreted that this discrepancy may result from the different characteristics of two straws (rice versus wheat) and/or of two tested soils.

Furthermore, our results showed that there is a higher abundance of type II than that of type I methanotrophs in all fertilization treatments. The methanotrophic metabolic differences and the environmental factors might result in this quantification discrepancy. Type I methanotrophs seemed to grow preferentially at high $\mathrm{O}_{2}$ and low $\mathrm{CH}_{4}$ concentrations, contrasting with type II methanotrophs which grow preferentially at low $\mathrm{O}_{2}$ and high $\mathrm{CH}_{4}$ concentrations (Amaral and Knowles 1995; Amaral et al. 1995). Since the soil samples were collected in the ricegrowing season, more $\mathrm{CH}_{4}$ was produced as well as more $\mathrm{O}_{2}$ was transferred from the atmosphere into the rice rhizosphere, thus maybe the type II methanotrophs profited 


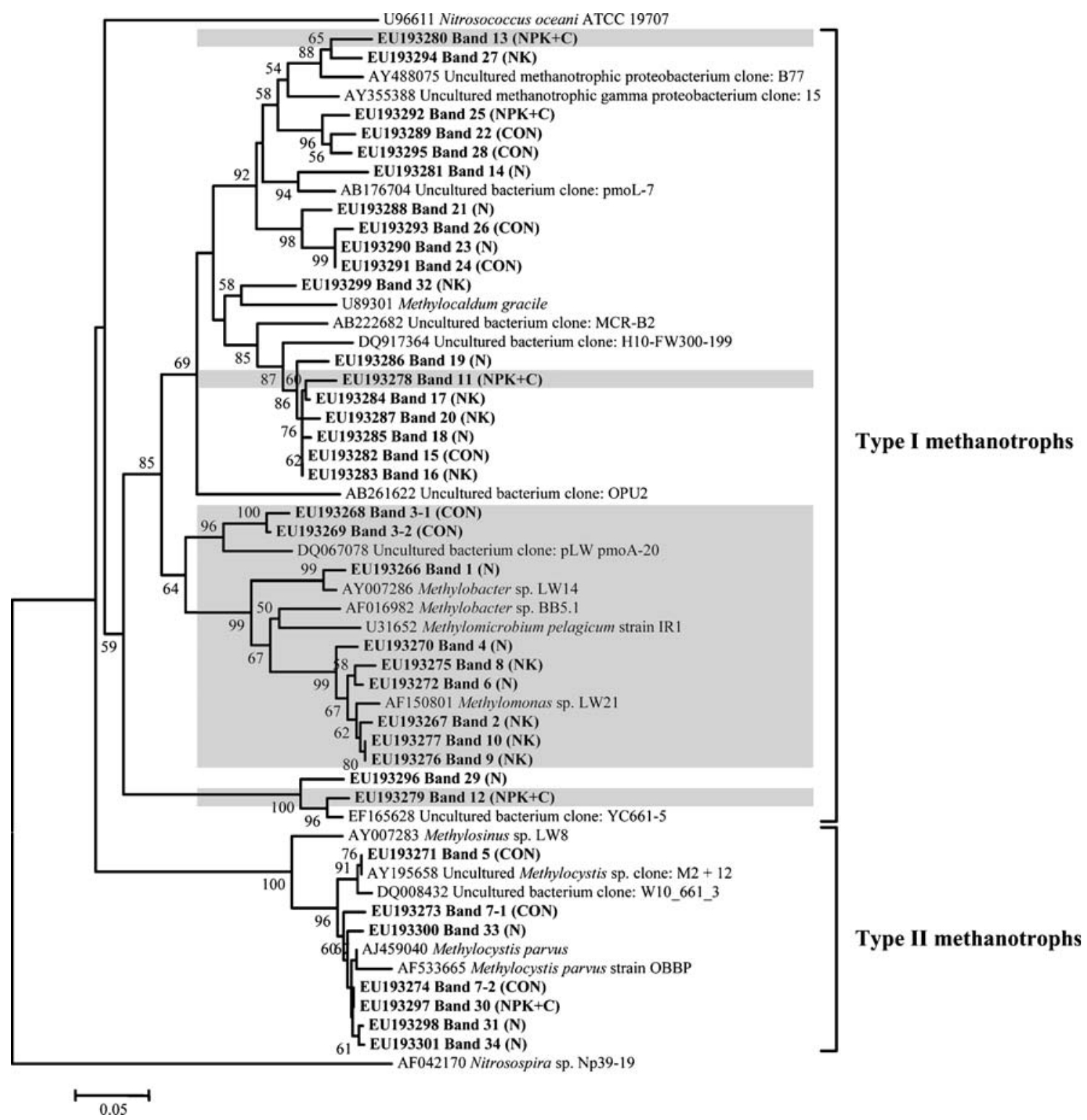

Fig. 3 Evolutionary distance tree of the derived amino acid sequence of pmo $A$ genes amplified from excised bands from methanotrophic DGGE gel of four long-term fertilization treatments. The shaded part indicates the sequences representing the bands which were excised from the upper part of the DGGE gel and were classified into type I

more in this competition by pursuing a low $\mathrm{O}_{2}$ and high $\mathrm{CH}_{4}$ environment and thus revealed a higher abundance than type I methanotrophs. In addition, such a phenomenon could also be explained that perhaps, apart from the fertilization, other factors like plant cultivation, water content, and temperature were responsible for the methane oxidation and propagation of the methanotrophs in the soil (Einola et al. 2007). A previous study similarly demonstrated that only type II populations were strongly correlated with soil porewater methane concentrations and rice growth (Macalady et al. 2002). Therefore, we conclude that the methanotrophs. Designation of the clones in bold includes the following information: accession number in the GenBank with the fertilization treatments in which the bands were excised in the parentheses. Bootstrap values $(>50 \%)$ are indicated at branch points. The scale bar represents $5 \%$ estimated sequence divergence

dominance of the type II methanotrophs might be caused by physiological and environmental factors.

4.2 Effects of fertilizer applications on soil methanotrophic community composition

Considering the minor effects of the NPK treatment on the methanotrophic abundance, only four other treatments $(\mathrm{CON}, \mathrm{N}, \mathrm{NK}$, and $\mathrm{NPK}+\mathrm{C})$ were selected to analyze the methanotrophic community structure using DGGE based on the amplification of the pmoA gene. Some distinct 
differences in the quantity of bands and diversity indices were found between the $\mathrm{N}$ and $\mathrm{NK}$ treatments, indicating that the soil methanotrophic community was clearly changed through the K-containing fertilization. Also, a recent study on a Chinese paddy soil demonstrated that $\mathrm{K}$ application had no effect on soil microbial parameters, the same as for $\mathrm{P}$ and $\mathrm{N}$ (Zhong and Cai 2007). It could be interpreted that the numbers of methanotrophs are typically in the order of $<1 \%$ of total bacteria (Kolb et al. 2003); thus, the clear distinction of a methanotrophic community would be most likely to be neglected in the total bacterial community analysis. A clearly complex diversity pattern was revealed in the $\mathrm{NPK}+\mathrm{C}$ treatment which might be a result of the strong $\mathrm{CH}_{4}$ production. Besides the chemical NPK, the addition of recycled crop residues was suggested to be vital to methanogenic archaeal and the methanogenesis in paddy soils (Conrad and Klose 2006). It is wellknown that the soil $\mathrm{CH}_{4}$ oxidation rate can be enhanced by higher $\mathrm{CH}_{4}$ concentrations, thus promoting the activity, growth, and eventually changing the community structure of methanotrophs (Bender and Conrad 1995). In summary, based on the DGGE profile, it was revealed that long-term application of fertilizers could change the soil methanotrophic community structure.

In this study, a visible and interesting discovery is the methanotrophic community composition of the upper part of the DGGE profile and the subsequent sequence analysis. The type I methanotrophs seemed to be more frequently detected. Many environmental factors such as soil water content and temperature changed continuously along with the growth of rice plants. A lot of work had been carried out to demonstrate the effects of these environmental factors on methane oxidation (King 1997; Smith et al. 2003; Einola et al. 2007). Our results indicated that type I methanotrophs relating to the genera of Methylobacter, Methylomicrobium, and Methylomonas seemed to be the most common methane oxidizers in the paddy soil receiving different fertilizations long-term. Similarly, the Methylobacter/Methylomonas-related methanotrophs were the active species in the paddy soils and differed from those in the forest soils (Mohanty et al. 2006). Also, our results were in agreement with an earlier work (Fjellbirkeland et al. 2001) in which type I sequences clustering with members of the genera Methylobacter, Methylomicrobium, and Methylomonas were most frequently detected in an agricultural soil.

\section{Conclusions}

Long-term fertilization regimes can differentially affect the abundance and composition of the methanotrophs. The inhibited effects on methanotrophic abundance were found in the $\mathrm{N}$ treatment, compared to the stimulated effects from the $\mathrm{NK}$ and $\mathrm{NPK}+\mathrm{C}$ treatments. On the other hand, the methanotrophic community structure also responded clearly to the different fertilization. The methanotrophic diversity of the NPK $+\mathrm{C}$ treatment was observed clearly distinguished from the other treatments. Furthermore, a clear shift was found in methanotrophic community composition based on the sequences and phylogenetic analysis. A significantly higher ratio of type I methanotrophic sequences clustering with the genera of Methylobacter, Methylomicrobium, and Methylomonas were detected in all treatments. In conclusion, the applications of nitrogen and potassium fertilizers could be important factors controlling the abundance, and some environmental factors such as temperature regulating the community composition, of the methanotrophs. Understanding of the major factors influencing the methanotrophic abundance and composition is vital for linking this functional community to soil ecosystem processes and sustainable management of rice cultivation.

\section{Recommendations and perspectives}

Methanotrophs are a fascinating group of microorganisms playing an important role in the biogeochemical carbon cycle and in the control of global climate change. However, it is still a challenge for the cultivation of the methanotrophs, although three isolates were very recently obtained in the extreme environments (Dunfield et al. 2007; Pol et al. 2007; Islam et al. 2008). Hence, future studies will undoubtedly be conducted via molecular techniques just like the applications in this study.

Acknowledgements This work was supported by the Chinese Academy of Sciences (KZCX2-YW-408, KZCX1-YW-0603), the National Basic Research Program of China (2005CB121105), and the Natural Science Foundation of China (40701087, 50621804).

\section{References}

Amaral JA, Knowles R (1995) Growth of methanotrophs in methane and oxygen counter gradients. FEMS Microbiol Lett 126:215220

Amaral JA, Archambault C, Richards SR, Knowles R (1995) Denitrification associated with groups I and II methanotrophs in a gradient enrichment system. FEMS Microbiol Ecol 18:289-298

Babu YJ, Nayak DR, Adhya TK (2006) Potassium application reduces methane emission from a flooded field planted to rice. Biol Fertil Soils 42:532-541

Bender M, Conrad R (1995) Effect of $\mathrm{CH}_{4}$ concentrations and soil conditions on the induction of $\mathrm{CH}_{4}$ oxidation activity. Soil Biol Biochem 27:1517-1527

Bodelier PLE, Roslev P, Henckel T, Frenzel P (2000) Stimulation by ammonium-based fertilizers of methane oxidation in soil around rice roots. Nature 403:421-424 
Conrad R, Klose M (2006) Dynamics of the methanogenic archaeal community in anoxic rice soil upon addition of straw. Eur J Soil Sci 57:476-484

Conrad R, Erkel C, Liesack W (2006) Rice Cluster I methanogens, an important group of Archaea producing greenhouse gas in soil. Curr Opin Biotechnol 17:262-267

Dubey SK, Singh JS (2000) Spatio-temporal variation and effect of urea fertilization on methanotrophs in a tropical dryland rice field. Soil Biol Biochem 32:521-526

Dunfield PF, Yuryev A, Senin P, Smirnova AV, Stott MB, Hou SB, Ly B, Saw JH, Zhou ZM, Ren Y, Wang JM, Mountain BW, Crowe MA, Weatherby TM, Bodelier PLE, Liesack W, Feng L, Wang L, Alam M (2007) Methane oxidation by an extremely acidophilic bacterium of the phylum Verrucomicrobia. Nature 450:879-882

Einola JKM, Kettunen RH, Rintala JA (2007) Responses of methane oxidation to temperature and water content in cover soil of a boreal landfill. Soil Biol Biochem 39:1156-1164

Fjellbirkeland A, Torsvik V, Øvreås L (2001) Methanotrophic diversity in an agricultural soil as evaluated by denaturing gradient gel electrophoresis profiles of pmoA, mxaF and $16 \mathrm{~S}$ rDNA sequences. Antonie van Leeuwenhoek 79:209-217

Ge Y, Zhang JB, Zhang LM, Yang M, He JZ (2008) Long-term fertilization regimes affect bacterial community structure and diversity of an agricultural soil in northern China. J Soils Sediments 8:43-50

Hanson RS, Hanson TE (1996) Methanotrophic bacteria. Microbiol Rev 60:439-471

He JZ, Shen JP, Zhang LM, Zhu YG, Zheng YM, Xu MG, Di HJ (2007) Quantitative analyses of the abundance and composition of ammonia-oxidizing bacteria and ammonia-oxidizing archaea of a Chinese upland red soil under long-term fertilization practices. Environ Microbiol 9:2364-2374

He JZ, Zheng Y, Chen CR, He YQ, Zhang LM (2008) Microbial composition and diversity of an upland red soil under long-term fertilization treatments as revealed by culture-dependent and culture-independent approaches. J Soils Sediments 8:349-358

Henckel T, Friedrich M, Conrad R (1999) Molecular analyses of the methane-oxidizing microbial community in rice field soil by targeting the genes of the 16S rRNA, particulate methane monooxygenase, and methanol dehydrogenase. Appl Environ Microbiol 65:1980-1990

Holmes AJ, Roslev P, McDonald IR, Iversen N, Henriksen K, Murrell JC (1999) Characterization of methanotrophic bacterial populations in soils showing atmospheric methane uptake. Appl Environ Microbiol 65:3312-3318

Horz HP, Yimga MT, Liesack W (2001) Detection of methanotroph diversity on roots of submerged rice plants by molecular retrieval of pmoA, mmoX, $m x a F$, and $16 \mathrm{~S}$ rRNA and ribosomal DNA, including $p m o A$-based terminal restriction fragment length polymorphism profiling. Appl Environ Microbiol 67:4177-4185

Hütsch BW (1998) Methane oxidation in arable soil as inhibited by ammonium, nitrite, and organic manure with respect to soil $\mathrm{pH}$. Biol Fertil Soils 28:27-35
Intergovernment Panel on Climate Change (IPCC) (2007) Climate Change 2007: the physical science basis. Working Group I contribution to the fourth assessment report of the intergovernmental panel on climate change. Cambrigde University Press, Cambridge

Islam T, Jensen S, Reigstad LJ, Larsen Ø, Birkeland NK (2008) Methane oxidation at $55^{\circ} \mathrm{C}$ and $\mathrm{pH} 2$ by a thermoacidophilic bacterium belonging to the Verrucomicrobia phylum. Proc Natl Acad Sci U S A 105:300-304

King GM (1997) Responses of atmospheric methane consumption by soils to global climate change. Glob Change Biol 3:351-362

Kolb S, Knief C, Stubner S, Conrad R (2003) Quantitative detection of methanotrophs in soil by novel pmoA-targeted real-time PCR assays. Appl Environ Microbiol 69:2423-2429

Krüger M, Frenzel P (2003) Effects of $\mathrm{N}$-fertilisation on $\mathrm{CH}_{4}$ oxidation and production, and consequences for $\mathrm{CH}_{4}$ emissions from microcosms and rice fields. Glob Change Biol 9:773-784

Lowe DC (2006) Global change: a green source of surprise. Nature 439:148-149

Macalady JL, McMillan AMS, Dickens AF, Tyler SC, Scow KM (2002) Population dynamics of type I and II methanotrophic bacteria in rice soils. Environ Microbiol 4:148-157

Mohanty SR, Bodelier PLE, Floris V, Conrad R (2006) Differential effects of nitrogenous fertilizers on methane-consuming microbes in rice field and forest soils. Appl Environ Microbiol 72:13461354

Mohanty SR, Bodelier PLE, Conrad R (2007) Effect of temperature on composition of the methanotrophic community in rice field and forest soil. FEMS Microbiol Ecol 62:24-31

Murrell JC, McDonald IR, Bourne DG (1998) Molecular methods for the study of methanotroph ecology. FEMS Microbiol Ecol 27:103-114

Pol A, Heijmans K, Harhangi HR, Tedesco D, Jetten MSM, Op den Camp HJM (2007) Methanotrophy below pH 1 by a new Verrucomicrobia species. Nature 450:874-878

Seghers D, Verthe K, Reheul D, Bulcke R, Siciliano SD, Verstraete W, Top EM (2003) Effect of long-term herbicide applications on the bacterial community structure and function in an agricultural soil. FEMS Microbiol Ecol 46:139-146

Shen JP, Zhang LM, Zhu YG, Zhang JB, He JZ (2008) Abundance and composition of ammonia-oxidizing bacteria and ammoniaoxidizing archaea communities of an alkaline sandy loam. Environ Microbiol 10:1601-1611

Smith KA, Ball T, Conen F, Dobbie KE, Massheder J, Rey A (2003) Exchange of greenhouse gases between soil and atmosphere: interactions of soil physical factors and biological processes. Eur J Soil Sci 54:779-791

Wise MG, McArthur JV, Shimkets LJ (1999) Methanotroph diversity in landfill soil: isolation of novel type I and type II methanotrophs whose presence was suggested by culture-independent $16 \mathrm{~S}$ ribosomal DNA analysis. Appl Environ Microbiol 65:4887-4897

Zhong WH, Cai ZC (2007) Long-term effects of inorganic fertilizers on microbial biomass and community functional diversity in a rice soil derived from quaternary red clay. Appl Soil Ecol 36:84-91 